\title{
Multimeric Presentation of RGD Peptidomimetics Enhances Integrin Binding and Tumor Cell Uptake
}

\author{
Arianna Pina, ${ }^{[a]}$ Malika Kadri, ${ }^{[b]}$ Daniela Arosio,,${ }^{[c]}$ Alberto Dal Corso, ${ }^{[a]}$ Jean-Luc Coll, ${ }^{[b]}$ Cesare \\ Gennari, ${ }^{*[a]}$ and Didier Boturyn*[d]
}

Abstract: The use of multimeric ligands is considered as

\begin{abstract}
a promising strategy to improve tumor targeting for diagnosis and therapy. Herein, tetrameric RGD peptidomimetics were designed to target $\alpha_{v} \beta_{3}$ integrin-expressing tumor cells. These compounds were prepared via an oxime chemoselective assembly of $c y c l o(D K P-R G D)$ ligands and a cyclodecapeptide scaffold that allows a tetrameric presentation. The resulting tetrameric RGD peptidomimetics were shown to improve $\alpha_{v} \beta_{3}$ integrin binding compared to the monomeric form. Interestingly, these compounds were also able to enhance tumor cell endocytosis in the same way as tetrameric RGD peptides. Altogether, the results show the potential of the tetrameric cyclo(DKP-RGD) ligands for in vivo imaging and drug delivery.
\end{abstract}

\section{Introduction}

Multivalent interactions play a key role in numerous biological processes including antibody-antigen, virus-cell, and cell-cell recognition. ${ }^{[1]}$ In particular, multivalent interactions enhance the avidity of multimeric species, resulting in an increased binding affinity compared to each individual binding unit. ${ }^{[2]}$ As an application of this concept to tumor-targeted therapy or diagnosis, multivalency could improve the tumor targeting performance of Small Molecule - Drug Conjugates (SMDCs), potentially approaching the well-known selectivity and binding strength of Antibody - Drug Conjugates (ADCs). ${ }^{[3]}$ To date, multivalency has found application in targeting agents for imaging, drug delivery or a combination thereof. ${ }^{[4]}$ Among relevant biological targets, the $\alpha_{v} \beta_{3}$ integrin subclass has received special attention as it is involved in tumor development including melanoma, prostate, breast, pancreatic carcinoma, and aggressive metastatic cancers. ${ }^{[5]}$ As $\alpha_{v} \beta_{3}$-expressing cells interact with the extracellular matrix via the recognition of the ubiquitous sequence RGD (Arg-GlyAsp), much research effort has been devoted to the design of RGD peptides ${ }^{[6]}$ and peptidomimetics ${ }^{[7]}$ that display this triad sequence. Various molecular scaffolds were used to construct multivalent ligands varying in size, shape and physico-chemical properties. ${ }^{[8]}$ The design of RGD clusters appears to be a prerequisite for effective integrin recognition. ${ }^{[9]}$ For a decade, the Grenoble group has shown that a cyclodecapeptide scaffold, named RAFT (Regioselectively Addressable Functionalized Template), exhibits suitable properties to design multivalent ligands. ${ }^{[10]}$ The benefit of RAFT-supported tetrameric RGD compounds for tumor therapy has been recently reported. ${ }^{[11]}$

Taking advantage of the cyclodecapeptide RAFT scaffold, herein we describe the modular synthesis and the in vitro characterization of tetrameric RGD peptidomimetic 1 (Figure 1). For this purpose, we exploited cyclo(DKP-RGD) peptidomimetic 2 derived from transdiketopiperazine (DKP). This compound was shown to be highly specific for $\alpha_{v} \beta_{3}$ integrin with nanomolar $I C_{50}$ values. ${ }^{[7]}$ The DKP 6 membered ring has been incorporated in the ligand structure to reduce its susceptibility to proteolytic degradation and to diminish conformational flexibility. Moreover, the presence of groups that can act as $\mathrm{H}$-bond donors (amide proton) or acceptors (amide carbonyl groups) allows for potentially favorable interactions of the DKP scaffold with biological targets. In the last decade, the Milan group has designed and synthetized several SMDCs employing the cyclo(DKP-RGD) ligand as recognition unit, confirming its potential for the selective delivery of cytotoxic agents. ${ }^{[12]}$

[a] Dr. A. Pina, Dr. A. Dal Corso, Prof. Dr. C. Gennari

Università degli Studi di Milano, Dipartimento di Chimica

Via C. Golgi 19, I-20133, Milan (Italy)

E-mail: cesare.gennari@unimi.it

Homepage: http://sites.unimi.it/gennarigroup/

[b] M. Kadri, Dr. J.-L. Coll

Institute for Advanced Biosciences, University Grenoble Alpes, INSERM, CNRS, Site Santé, Allée des Alpes, 38700 La Tronche (France)

[c] Dr. D. Arosio

CNR, Istituto di Scienze e Tecnologie Chimiche (SCITEC) "Giulio Natta", Via C. Golgi, 19, I-20133, Milan (Italy)

[d] Dr. D. Boturyn

Department of Molecular Chemistry, University Grenoble Alpes, CNRS, 570, rue de la chimie, CS 40700, 38041 GRENOBLE Cedex 9 (France)

E-mail: didier.boturyn@univ-grenoble-alpes.fr

Supporting information for this article is given via a link at the end of the document. 

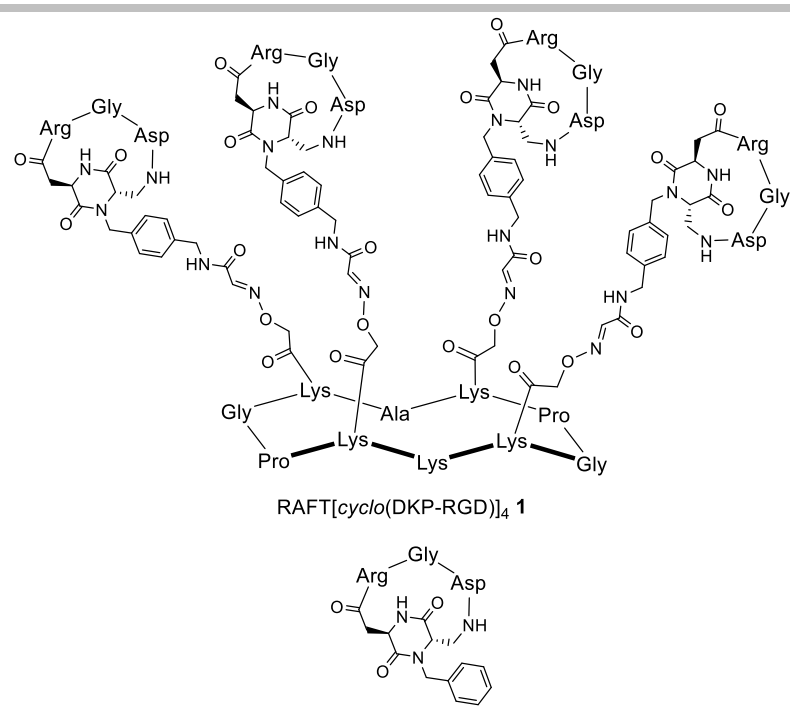

cyclo(DKP-RGD) 2

Figure 1. Molecular structure of the $\alpha_{v} \beta_{3}$ integrin tetrameric and monomeric cyclo(DKP-RGD) containing ligands (1 and $\mathbf{2}$ ).

\section{Results and Discussion}

Access to multimeric compound $\mathbf{1}$ was carried out following Scheme 1, using the highly chemoselective and efficient oxime ligation protocol. For this purpose, a serine residue was introduced into the RGD peptidomimetic $\mathbf{3}$, the functionalized version of compound $\mathbf{2}$, bearing an amino moiety suitable for conjugation. ${ }^{[12 a]}$ Oxidative cleavage with sodium periodate of the amino-alcohol moiety of serinecontaining peptidomimetic $\mathbf{4}$ afforded the desired glyoxylyl RGD compound $\mathbf{5}$ in good overall yield (74\%). In parallel, cyclodecapeptide 6 was prepared by a combination of SPPS (solid phase peptide synthesis) and solution strategy. ${ }^{[13]}$ The 1-ethoxyethylidene group was selected to protect the aminooxy functions due to its stability under SPPS conditions and easy removal under the mild acidic conditions used for the oxime ligation. Then, one-pot aminooxy deprotection of $\mathbf{6}$ and subsequent ligation of aldehyde containing-compound $\mathbf{5}$ were performed in an aqueous trifluoroacetic acid solution, affording the expected tetrameric RAFT[cyclo(DKP-RGD) $]_{4}$ peptidomimetic 1 in $44 \%$ yield after RP-HPLC purification. Compound 1 was characterized by ESI-MS and the observed $m / z$ was found in excellent agreement with the calculated value (see the Supporting Information).
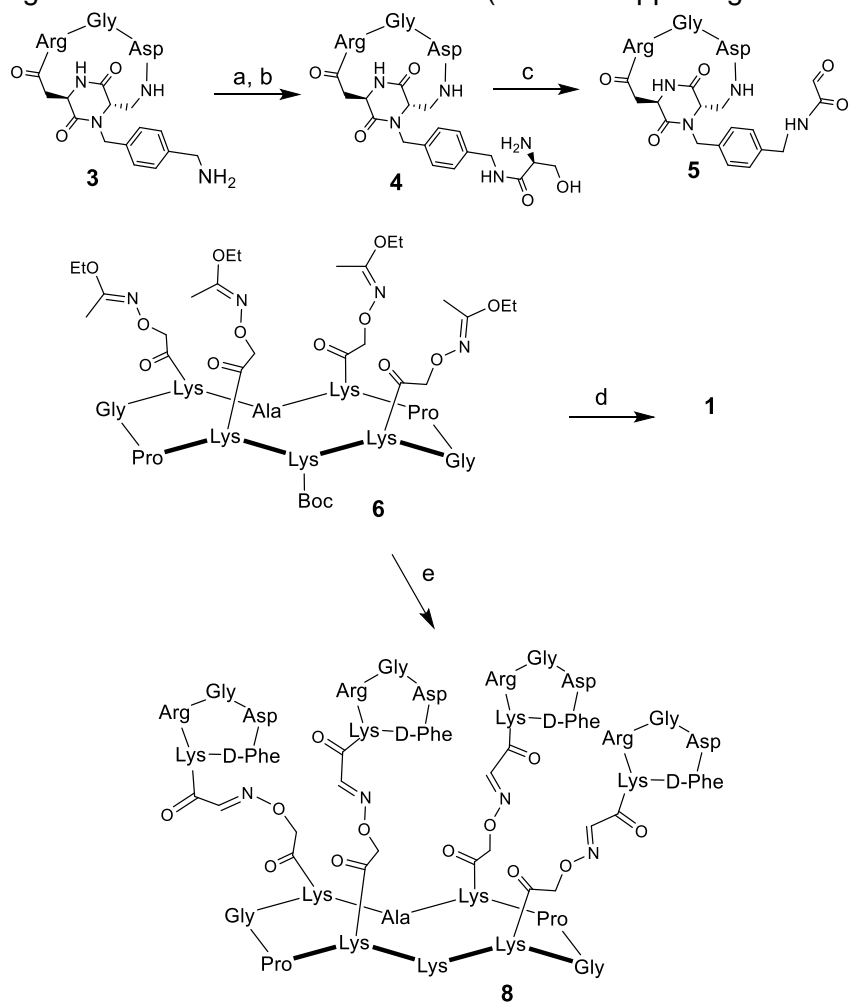

Scheme 1. Synthesis of tetrameric RAFT[cyclo(DKP-RGD) $]_{4}$ ligand 1 and tetrameric RAFT[cyclo(RGDfK) $]_{4}$ ligand 8. Reagents and conditions: a) Boc-Ser( $t$-Bu)-ONHS, DMF, DIPEA, RT, 2 h; b) TFA/ $\mathrm{H}_{2} \mathrm{O}$ (19/1), RT, 2 h; c) NalO${ }_{4}, \mathrm{H}_{2} \mathrm{O}$, RT, 20 min; d) 5, TFA/H $\mathrm{H}_{2} \mathrm{O}$ (7/3), RT, 30 min; e) TFA/ $\mathrm{H}_{2} \mathrm{O}$ (7/3), cyclo(RGDFK)-CO-CHO, $\mathrm{RT}, 30 \mathrm{~min}$. 
In parallel, control compounds such as the monomeric cyclo(DKP-RGD) $2,{ }^{[7 e]}$ cyclo(DKP-R $\left.\beta A D\right) ~ 7,{ }^{[14]}$ and the peptidic analog $\mathrm{RAFT}[\mathrm{cyclo}(\mathrm{RGDfK})]_{4} \mathbf{8}^{[\mathrm{dd}]}$ were prepared as previously described. It is important to note that incorporation of $\beta$-alanine $(\beta A)$ instead of glycine within the RGD sequence is known to result in a complete loss of biological activity. ${ }^{[9 d, 14]}$

The compounds were then examined in vitro for their ability to inhibit biotinylated vitronectin binding to the purified $\alpha_{v} \beta_{3}$ receptor. Experiments were performed by incubating immobilized integrin with solutions of the compounds at different concentrations $\left(10^{-12}\right.$ to $\left.10^{-5} \mathrm{M}\right)$ in the presence of biotinylated vitronectin $\left(1 \mu \mathrm{g} \cdot \mathrm{mL}^{-1}\right)$. The $\mathrm{IC}_{50}$ values are shown in Table 1 . As expected, the control compound cyclo(DKP-RßAD) 7 displayed strongly reduced binding affinity, that is three orders of magnitude lower than $c y c l o(D K P-R G D) 2$ Interestingly, while functionalization of the parent $c y c l o(D K P-R G D)$ ligand 2 with the $p$-aminomethyl group, leading to amine 3 and derivatives, generally results in a lower $\alpha_{v} \beta_{3}$ integrin binding affinity (e.g. $I C_{50}$ of amine $3=26.4 \pm 3.7 \mathrm{nM}$ ), ${ }^{[12 a]}$ the tetrameric RAFT[cyclo(DKP-RGD) $]_{4}$ peptidomimetic 1 showed subnanomolar affinity, with an $\mathrm{IC}_{50}$ lower than that of monomeric $c y c l o(D K P-R G D)$ 2 (4.5-fold decrease of $\mathrm{IC}_{50}$ ). This result highlights the improvement of the binding affinity through multiple presentation of the integrin ligand. However, we found that the binding potency of peptidomimetic $\mathbf{1}$ is lower than that of the peptidic analog $\mathbf{8}$, paralleling the relative affinity of the respective monomeric ligands [cf. the $\mathrm{IC}_{50}$ value of $c y c l o$ (DKP-RGD) $2=4.5 \pm 1.1 \mathrm{nM}$ with that of $c y c l o(R G D f K)$ $=1.4 \pm 0.2 \mathrm{nM}]{ }^{\left[{ }^{[15}\right]}$ Based on previous studies, optimization of the linker lengths could be important to improve biological activity. ${ }^{[16]}$

Table 1. Inhibition of biotinylated vitronectin binding to the $\alpha_{v} \beta_{3}$ receptor.

\begin{tabular}{ccc}
\hline Compound & Structure & $\begin{array}{c}\mathrm{a}_{\mathrm{v}} \beta_{3} \\
\mathrm{IC}_{50}[\mathrm{~nm}]^{[\mathrm{a}]}\end{array}$ \\
\hline $\mathbf{1}$ & RAFT $[\text { cyclo(DKP-RGD) }]_{4}$ & $0.98 \pm 0.27$ \\
$\mathbf{7}$ & cyclo(DKP-RGD) & $4.5 \pm 1.1^{[\mathrm{b}]}$ \\
$\mathbf{8}$ & cyclo(DKP-RßAD) & $1550 \pm 226^{[\mathrm{cc}]}$ \\
\hline
\end{tabular}

[a] $I \mathrm{C}_{50}$ values were calculated as the concentration of compound required for $50 \%$ inhibition of biotinylated vitronectin binding, as estimated by GraphPad Prism software. All values are the arithmetic mean \pm the standard deviation (SD) of triplicate determinations; [b] see ref. ${ }^{[7]}$; [c] see ref. ${ }^{[14]}$.

To evaluate the interactions of the RAFT[cyclo(DKP-RGD) $]_{4}$ peptidomimetic with cancer cells, we introduced a near-infra red (NIR) fluorescent reporter such as Cyanine 5 (Cy5) (Scheme 2). Cy5 dye was conjugated to the lysine side-chain of compounds $\mathbf{1}$ and $\mathbf{8}$, and to the exocyclic amino group of $\mathbf{3}$ under neutral conditions ( $\mathrm{pH} 8.0$ ), affording the fluorescent conjugates $\mathbf{9 - 1 1}$ in good yields after RPHPLC purification. Fluorescent compounds were characterized by ESI-MS: $m / z$ were found to be in agreement with the calculated values (see the Supporting Information).



Scheme 2. Synthesis of fluorescent compounds 9-11. Reagents and conditions: a) Cy5-NHS, DIPEA (pH 8.0), DMF, $3 \mathrm{~h}, \mathrm{RT}$.

The recognition potency of the different compounds was determined by using flow cytometry assays (Figure 2). For this purpose, human U87 glioblastoma and M21 melanoma that express $\alpha_{v} \beta_{3}$ integrin to a similar extent (see Figure S1 in the Supporting Information), and the $\alpha_{v}$-negative variant M21-L cell lines were chosen. As observed with the $\alpha_{v} \beta_{3}$ receptor (Table 1), we confirmed the high potency of the fluorescent RAFT[cyclo(DKP-RGD)] 9 compared to the monovalent analog cyclo(DKP-RGD) 10, using U87 glioblastoma in 
particular and, to a lesser degree, M21 melanoma cell lines. It is worth mentioning the comparable biological activity of both tetrameric RGD compounds $\mathbf{9}$ and 11, which highlights the biological potential of $\mathbf{9}$ for tumor targeting. In contrast, compound $\mathbf{1 0}$ may be less efficient on different cell lines expressing similar levels of integrin $\alpha_{v} \beta_{3}$ because this receptor may not behave identically in each cell line. As expected, only low binding was observed on the M21-L $\alpha_{v}$-negative control cell line (Figure 2c).

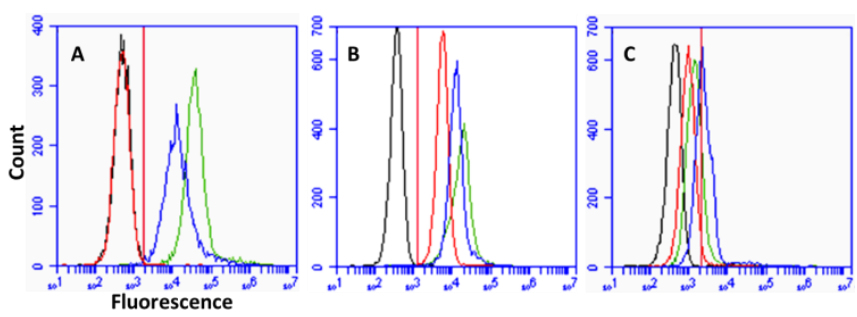

Figure 2. Flow cytometry analysis of A) U87, B) M21, and C) M21L. Experiments were performed by incubating cells with $0.5 \mu \mathrm{M}$ of compounds 9 (blue plot), 10 (red plot), 11 (green plot) and without compound (black plot) in Dulbecco's modified eagle medium (DMEM) for $30 \mathrm{~min}$ at $37^{\circ} \mathrm{C}$.

To further investigate the potential of DKP-compound for drug delivery, we examined the behavior of compounds 9-11 in the presence of cells expressing $\alpha_{v} \beta_{3}$ integrin, by using confocal microscopy. As shown in Figure 3, NIR fluorescent compounds were detected in the cytoplasm with the presence of small vesicles. Weak signal was observed when cells were incubated with fluorescent monomeric cyclo(DKP-RGD) $\mathbf{1 0}$ (Figure 3c) reinforcing the observation that the multimeric presentation clearly improves cell targeting Similar uptake was found for tetrameric RGD compounds $\mathbf{9}$ and 11. Moreover, the presence of small vesicles suggests that the internalization occurs via classical pathways observed for RGD compounds ${ }^{[9 \mathrm{~d}, 17]}$ and natural ligands such as vitronectin. ${ }^{\left[{ }^{[18]} \text { We obtained }\right.}$ similar results when M21 cells were incubated with compounds 9-11 (see Figure S2 in the Supporting Information). Notably, the presence of the fluorescent conjugates $\mathbf{9 - 1 1}$ was never detected in the nuclei of U87 and M21 cells.
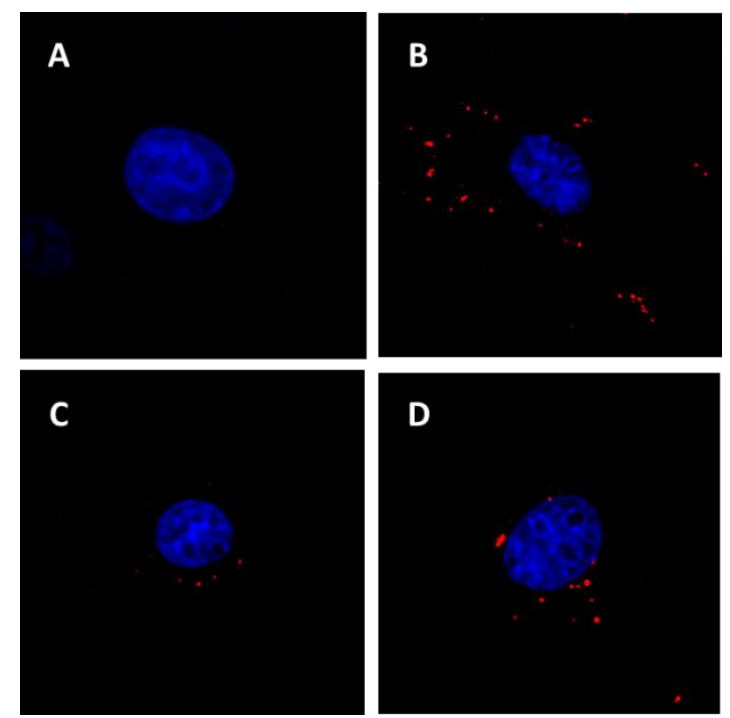

Figure 3. Representative fluorescence confocal images from living U87 cells ( $\left.10^{5} \mathrm{cells} / \mathrm{mL}\right)$ incubated for 30 min at $37^{\circ} \mathrm{C}$ a) without compound, b) with 9 ( $\left.0.5 \mu \mathrm{M}\right)$, c) with $10(0.5 \mu \mathrm{M})$, and d) with $11(0.5 \mu \mathrm{M})$. Nucleus was stained by using Hoechst 33342 dye.

\section{Conclusions}

In recent years, much research effort has been devoted to improve the tumor-targeting properties of RGD compounds. ${ }^{[19]}$ In particular, multimeric systems were shown to give superior in vivo pharmacokinetics than monomeric RGD peptides. In the present work, tetrameric RAFT[cyclo(DKP-RGD)] 4 peptidomimetics were prepared through a convergent synthetic scheme. We have shown that this multimeric design results in improved $\alpha_{v} \beta_{3}$ integrin binding and stronger cancer cell uptake. Altogether, our results demonstrate the potential of the tetrameric RAFT[cyclo(DKP-RGD) $]_{4}$ peptidomimetics for in vivo imaging and drug delivery. The use of $c y c l o(D K P-$ RGD)-based peptidomimetics instead of traditional RGD peptides should also provide interesting properties such as increased stability towards proteolytic degradation and a better pharmacokinetic perspective. Additional in vivo experiments in mice concerning pharmacokinetic assessment are in progress and will be reported in due course. 


\section{Experimental Section}

All compounds were prepared according to literature procedures. Compounds $\mathbf{2 , 7 , 8}$, and $\mathbf{1 1}$ were prepared as previously described. ${ }^{[7,9 \mathrm{9d}, 14]}$ Detailed procedures of compounds $\mathbf{1}, \mathbf{9}$ and 10, analytical data and biological experiments are reported in the Supporting Information.

\section{Acknowledgements}

We thank Ministero dell'Università e della Ricerca (PRIN 2015 project 20157WW5EH) for financial support. Arianna Pina thanks the Erasmus+ Programme for a six month traineeship during her stage in Grenoble.This work was supported by the CNRS, the University Grenoble Alpes, the "Communauté d'agglomération Grenoble-Alpes Métropole" (Nanobio program) and LabEx ARCANE and CBHEUR-GS (ANR-17-EURE-0003). The authors wish to acknowledge the support from the ICMG chemistry platform, Grenoble, on which the peptide synthesis has been performed.

Keywords: peptidomimetics $\bullet$ multivalency $\bullet$ RGD peptide $\bullet$ cell targeting $\bullet$ integrin

[1] M. Mammen, S. K. Choi, M. Whitesides, Angew. Chem. 1998, 110, 2908-1953; Angew. Chem. Int. Ed. 1998, 37, $2754-2794$.

[2] (a) A. Barnard, D. K. Smith, Angew. Chem. Int. Ed. 2012, 51, 6572-6581; (b) S. M. Deyev, E. N. Lebedenko, Bioessays 2008, 30, 904-918; (c) E. Mahon, M. Barboiu, Org. Biomol. Chem. 2015, 13, 10590-10599.

[3] (a) R. Mahato, W. Tai, K. Cheng, Adv. Drug Delivery Rev. 2011, 63, 659-670; (b) T. Lammers, F. Kiessling, W. E. Hennink, G. Storm, J. Controlled Release 2012, 161, 175-187; (c) N. Krall, J. Scheuermann, D. Neri, Angew. Chem. Int. Ed. 2013, 52, 1384-1402; (d) G. Casi, D. Neri, J. Med. Chem. 2015, 58, 87518761; (e) P. T. Wong, S. K. Choi, Chem. Rev. 2015, 115, 3388-3432.

[4] For some examples: (a) M. Janssen, W. J. G. Oyen, L. F. A. G. Massuger, C. Frielink, I. Dijkgraaf, D. S. Edwards, M. Radjopadhye, F. H. M. Corstens, O. C. Boerman, Cancer Biother. Radiopharm. 2002, 17, 641-646; (b) G. Thumshirn, U. Hersel, S. L. Goodman, H. Kessler, Chem. Eur. J. 2003, 9, 2717-2725; (c) D. J. Welsh, D. K. Smith, Org. Biomol. Chem. 2011, 9, 4795-4801; (d) N. Krall, F. Pretto, D. Neri, Chem. Sci. 2014, 5, 3640-3644; (e) A. Bianchi, D. Arosio, P. Perego, M. De Cesare, N. Carenini, N. Zaffaroni, M. De Matteo, L. Manzoni, Org. Biomol. Chem. 2015, 13, 7530-7541; (f) V. Lopez-Rodriguez, C. Galindo Sarco, F. O. Garcia-Perez, G. Ferro-Flores, O. Arrieta, M. A. Avila-Rodriguez, J. Nucl. Med. 2016, 57, 404-409; (g) C. Zhai, G. M. Franssen, M. Petrik, P. Laverman, D. Summer, C. Rangger, R. Haubner, H. Haas, C. Decristoforo, Mol. Imaging Biol. 2016, 18, 758-767; (h) C. Imberti, S. Y. A. Terry, C. Cullinane, F. Clarke, G. H. Cornish, N. K. Ramakrishnan, P. Roselt, A. P. Cope, R. J. Hicks, P. J. Blower, M. T. Ma, Bioconjugate Chem. 2017, 28, 481-495; (i) B. C. Lee, B. S. Moon, J. S. Kim, J. H. Jung, H. S. Park, J. A. Katzenellenbogen, S. E. Kim, RSC Adv. 2013, 3, 782-792; (I) M. H. Lee, J. L. Sessler, J. S. Kim, Acc. Chem. Res. 2015, 48, 2935-2946; (m) L. Röglin, E. H. M. Lempens, E. W. Meijer, Angew. Chem. Int. Ed. 2011, 50, 102-112; (n) A. Arsiwala, A. Castro, S. Frey, M. Stathos, R. S. Kane, Chem. Asian J. 2019, 14, 244-255.

[5] (a) J. S. Desgrosellier, L. A. Barrnes, D. J. Shields, M. Huang, S. K. Lau, N. Prévost, D. Tarin, S. J. Shattil, D. A. Cheresh, Nat. Med., 2009, 15, 1163-1169; (b) S. Raab-Westphal, J. F. Marshall, S. L. Goodman, Cancers 2017, 9, 110.

[6] (a) R. Haubner, W. Schmitt, G. Hölzemann, S. L. Goodman, A. Jonczyk, H. Kessler, J. Am. Chem. Soc. 1996,118, 7881-7891; (b) M. A. Dechantsreiter, E. Planker, B. Mathä, E. Lohof, G. Hölzemann, A. Jonczyk, S. L. Goodman, H. Kessler, J. Med. Chem. 1999, 42, 3033-3040.

[7] (a) G. Casiraghi, G. Rassu, L. Auzzas, P. Bureddu, E. Gaetani, L. Battistini, F. Zanardi, C. Curti, G. Nicastro, L. Belvisi, I. Motto, M. Castorina, G. Giannini, C. Pisano, J. Med. Chem. 2005, 48, 7675-7687; (b) L. Belvisi, T. Riccioni, M. Marcellini, I. Chiarucci, D. Efrati, L. Vesci, D. Potenza, C. Scolastico, L. Manzoni, K. Lombardo, M. A. Stasi, B. Nico, D. Ribatti, M. Presta, P. Carminati, C. Pisano, Mol. Cancer Ther. 2005, 4, 1670-1680; (c) F. Schumann, A. Müller, M. Koksch G. Müller, N. Sewald, J. Am. Chem. Soc. 2000, 122, 12009-12010; (d) S. Urman, K. Gaus, Y. Yang, U. Strijowski, N. Sewald, S. De Pol, O. Reiser, Angew. Chem. 2007, 119, 4050-4053; Angew. Chem. Int. Ed. 2007, 46, 3976-3978; (e) M. Marchini, M. Mingozzi, R. Colombo, I. Guzzetti, L. Belvisi, F. Vasile, D. Potenza, U. Piarulli, D. Arosio, C. Gennari, Chem. Eur. J. 2012, 18, 6195-6207.

[8] (a) K. Temming, R. M. Schiffelers, G. Molema, R. J. Kok, Drug Resist. Update 2005, 8, 381-402; (b) F. Danhier, A. Le Breton, V. Préat, Mol. Pharmaceutics 2012, 9, 2961-2973.

[9] (a) H. D. Maynard, S. Y. Okada, R. H. Grubbs, J. Am. Chem. Soc., 2001, 123, 1275-1279; (b) R. J. Kok, A. J. Schraa, E. J. Bos, H. E. Moorlag, S. A. Asgeirsdottir, M. Everts, D. K. F. Meijer, G. Molema, Bioconjugate Chem. 2002, 13, 128-135; (c) G. Thumshirn, U. Hersel, S. L. Goodman, H. Kessler, Chem. Eur. J. 2003, 9, 2717-2725; (d) D. Boturyn, J.-L. Coll, E. Garanger, M.-C. Favrot, P. Dumy, J. Am. Chem. Soc. 2004, 126, 5730-5739; (e) Y. Wu, X. Z. Zhang, Z. M. Xiong, Z. Cheng, D. R. Fisher, S. Liu, S. S. Gambhir, X.-Y.Chen, J. Nucl. Med. 2005, 46, 1707-1718; ( f) Y. Ye, S. Bloch, B. Xu, S. Achilefu, J. Med Chem. 2006, 49, 2268-2275; (g) I. Dijkgraaf, A. Y. Rijnders, A. Soede, A. C. Dechesne, G. Wilma van Esse, A. J. Brouwer, F. H. M. Corstens, O. C. Boerman, D. T. S. Rijkers, R. M. J. Liskamp, Org. Biomol. Chem. 2007, 5, 935-944; S. Chakraborty, J. Shi, Y.-S. Kim, Y. Zhou, B. Jia, F. Wang, S. Liu, Bioconjugate Chem. 2010, 21, 969-980; (i) D. J. Welsh, D. K. Smith, Org. Biomol. Chem. 2011, 9, 4795-4801; (j) A. Raposo Moreira Dias, A. Pina, A. Dal Corso, D. Arosio, L. Belvisi, L. Pignataro, M. Caruso, C Gennari, Chem. Eur. J. 2017, 23, 14410-14415.

[10] D. Boturyn, E. Defrancq, G. T. Dolphin, J. Garcia, P. Labbe, O. Renaudet, P. Dumy, J. Pept. Sci. 2008, 14, $224-240$.

[11] (a) C. H. F. Wenk, F. Ponce, S. Guillermet, C. Tenaud, D. Boturyn, P. Dumy, D. Watrelot-Virieux, C. Carozzo, V. Josserand, J.-L. Coll, Cancer Lett. 2013, 334, 188-195; (b) A. Karageorgis, M. Claron, R. Jugé, C. Aspord, C. Leloup, F. Thoreau, J. Kurcharczak, J. Plumas, M. Henry, A. Hurbin, P. Verdié, J. Martinez, G. Subra, P. Dumy, D. Boturyn, A. Aouacheria, J.-L. Coll, Mol. Ther. 2017, 25, 534-546; (c) B. Liet, E. Laigre, D. Goyard, B. Todaro, C. Tiertant, D. Boturyn, N. Berthet, O. Renaudet, Chem. Eur. J. 2019, 25, 15508-15515; (d) A. Borbély, F. Thoreau, E. Figueras, M. Kadri, J.-L. Coll, D. Boturyn, N. Sewald, Chem. Eur. J. 2020, DOI: 10.1002/chem.201905437.

[12] (a) R. Colombo, M. Mingozzi, L. Belvisi, D. Arosio, U. Piarulli, N. Carenini, P. Perego, N. Zaffaroni, M. De Cesare, V. Castiglioni, E. Scanziani C. Gennari, J. Med. Chem. 2012, 55, 10460-10474; (b) A. Dal Corso, M. Caruso, L. Belvisi, D. Arosio, U. Piarulli, C. Albanese, F. Gasparri, A. Marsiglio, F. Sola, S. Troiani, B. Valsasina, L. Pignataro, D. Donati, C. Gennari, Chem. Eur. J. 2015, 21, 6921-6929; (c) S. Zanella, S. Angerani, A. Pina, P. Lopez Rivas, C. Giannini, S. Panzeri, D. Arosio, M. Caruso, F. Gasparri, I. Fraietta, C. Albanese, A. Marsiglio, L. Pignataro, L. Belvisi, U. Piarulli, C. Gennari, Chem. Eur. J. 2017, 23, 79107914; (d) P. López Rivas, L. Bodero, B. Korsak, T. Hechler, A. Pahl, C. Müller, D. Arosio, L. Pignataro, C. Gennari, U. Piarulli, Beilstein J. Org. Chem. 2018, 14, 407-415; (e) A. Pina, A. Dal Corso, M. Caruso, L. Belvisi, D. Arosio, S. Zanella, F. Gasparri, C. Albanese, U. Cucchi, I. Fraietta, A. Marsiglio, L. Pignataro, D. Donati, C. Gennari, ChemistrySelect 2017, 2, 4759-4766; (f) P. López Rivas, I. Ranđelović, A. Raposo Moreira Dias, A. Pina, D. Arosio, J. Tovari, G. Mező, A. Dal Corso, L. Pignataro, C. Gennari, Eur. J. Org. Chem. 2018, 2902-2909.

[13] S. Foillard, M. Ohsten Rasmussen, J. Razkin, D. Boturyn, P. Dumy, J. Org. Chem. 2008, 73, 983-991.

[14] A. Raposo Moreira Dias, A. Pina, A. Dean, H. G. Lerchen, M. Caruso, F. Gasparri, I. Fraietta, S. Troiani, D. Arosio, L. Belvisi, L. Pignataro, A. Dal Corso, C. Gennari, Chem. Eur. J. 2019, 25, 1696-1700. 
[15] M. Civera, D. Arosio, F. Bonato, L. Manzoni, L. Pignataro, S. Zanella, C. Gennari, U. Piarulli, L. Belvisi, Cancers 2017, 9, 128.

[16] A. Grassin, M. Jourdan, P. Dumy, D. Boturyn, ChemBioChem 2016, 17, 515-520

[17] L. Sancey, E. Garanger, S. Foillard, G. Schoehn, A. Hurbin, C. Albiges-Rizo, D. Boturyn, C. Souchier, A. Grichine, P. Dumy, J.-L. Coll, Mol Ther. 2009, 17, 837-843.

[18] L. M. Memmo, P. McKeown-Longo, J. Cell. Sci. 1998, 111, 425-433.

[19] H. Chen, G. Niu, H. Wu, X. Chen, Theranostics 2016, 6, 78-92. 
